\title{
Lurking and L2 Learners on a Facebook Group: The Voices of the Invisibles
}

\author{
Latisha Asmaak Shafie ${ }^{1}$, Aizan Yaacob ${ }^{2} \&$ Paramjit Kaur Karpal Singh ${ }^{2}$ \\ ${ }^{1}$ Academy of Language Studies, Universiti Teknologi MARA Perlis, Arau, Perlis, Malaysia \\ ${ }^{2}$ School of Education \& Modern Languages, Universiti Utara Malaysia, Sintok, Malaysia \\ Correspondence: Latisha Asmaak Shafie, Academy of Language Studies, Universiti Teknologi MARA Perlis, \\ 02600 Arau, Perlis, Malaysia. Tel: 6-04-9882000. E-mail: ciklatisha@perlis.uitm.edu.my
}

\author{
Received: November 22, 2015 Accepted: January 4, 2016 Online Published: January 5, 2016 \\ doi:10.5539/elt.v9n2p1 \\ URL: http://dx.doi.org/10.5539/elt.v9n2p1
}

\begin{abstract}
This qualitative research investigates the practice of lurking among English as a second language (ESL) learners in a Facebook group discussion. Lurking is a term used to describe the activity of following and observing any online discussions or activities without contributing to the discussions. Lurkers are often accused of being invisible and passive participants. Facebook groups with international members usually uses English as the medium of communication in their group discussions. It is a norm for L2 learners to lurk in the group. These L2 learners often do not have the required English language proficiency and the confidence to participate actively in the group they join. This study explores lurking behaviours of three participants in learning English in informal Facebook contexts. This study uses a qualitative case study. The study involved three L2 learners who were university students and members of a Facebook group. The study involved online observation and semi-structured interviews with these three participants. Their Facebook accounts and a common Facebook group were observed for 14 weeks, and after the online observation, the participants were interviewed. Data collected from online observation and semi-structured interviewed were analysed and managed using Atlas.ti 7. The study reveals five emerging themes such as that lurkers have poor online communication skills, lack of confidence, learning by lurking, lack of a sense of belonging and lurking is the norm of Facebook groups.
\end{abstract}

Keywords: lurkers, Facebook, online communication skills, lurking, lack of confidence, ESL learners

\section{Introduction}

The Malaysian education system has often celebrated multilingualism to cater Malaysia's multiracial citizens. Bahasa Malaysia is the language of instruction in national schools while Tamil and Mandarin are used in vernacular schools. Even though Bahasa Malaysia is not the language of instruction for the vernacular schools, it is taught as a compulsory language. English is taught as a second language in Malaysia. However, there is a discrepancy in English language proficiency levels between urban and rural students. The students do not have many opportunities to communicate in English if their communities consist of people who communicate in their native languages. The main reason for low English language proficiency is due to the lack of exposure to the language outside of English language classrooms (Normazidah, Koo, \& Hazita, 2012).

The ubiquity of the Internet influences the growth of web-based learning to complement the traditional classes. Therefore, the Internet presents ample opportunities for ESL learners to improve their language proficiency through various social network sites such as Facebook, Instagram and Twitter. Facebook has rich opportunities for L2 learners of English language to communicate with native speakers and fluent speakers of English through its services such as Facebook groups and Facebook pages. Studies on Facebook as informal English language learning sites indicate that Facebook offers rich language enhancement activities for the students to improve their English language proficiency levels (Melor, Salehi, \& Chenzi, 2012; Omar et al., 2012; Shih, 2011; Wu \& Hsu, 2011; Kabilan, Ahmad, \& Zainol, 2010)

Lecturers often use online group forums for group discussions and class learning as online forum discussions gain popularity among students. However, many studies show of non-participation among students in the participation of online group discussions as some students prefer to observe silently without participating (Antin \& Cheshire, 2010; Benevenuto et al. 2009; Bernstein, Bakshy, Burke, \& Karrer, 2013). Lurking in this study is 
defined as observing silently and posting minimal or no posts at all. These students only read the posts without contributing to the contents of the discussions. Lurkers have received a lot of attention since the Internet was first introduced. Lurkers are identified as passive participants who do not contribute any content to any online discussions. Lurkers are often assumed not to learn effectively as they do not participate actively in the discussions of their Facebook group activities to maximise their language learning experiences. Most of the Internet studies concentrated on active users as these users contributed to the contents (Nguyen et al., 2013; Uysal \& Croft, 2011; Hannon, Bennett, \& Smyth, 2010; Gayo-Avello, 2012) which lead to inaccurate data on the Internet activities and users.

\section{Literature Review}

Computer-mediated communication (CMC) consists of asynchronous and synchronous communication. Computer-mediated communication is defined as communication between individuals using computer networks such as instant messaging, video conferencing, chats and others. Computer-mediated communication allows L2 learners to communicate at their pace and time (Romiszowski \& Mason, 2004; Ranjit \& Mohamed, 2008; Wu \& Hiltz, 2004). Social media depends on the contributions of the users as it is users- generated contents. The contents are then shared by the users. There were many studies conducted on the university's learners' management systems in Malaysia on learners' asynchronous learning interactions (Amelia, Mohamed, \& Rosseni, 2009; Berhannudin \& Wan, 2009; Ranjit \& Mohamed, 2010). A growing number of studies on the educational usage of Facebook (Buzzetto-More, 2012, Melor \& Hadi, 2012; Sewlyn, 2009; Shih, 2011; White 2009).

Lurking is a common behaviour as illustrated in many studies (Nonnecke, Preece, \& Andrews, 2004; Ridings, Gefen, \& Arinze, 2006; Nonnecke \& Preece, 2000; Muller et al., 2010; Antin \& Cheshire, 2010; Benevenuto et al., 2009; Bernstein et al., 2013). Lurking receives both aspects. There are studies that described lurkers as free-riders (Kollock \& Smith, 1996), yet there are studies that described lurking as passive participation (Soroka \& Rafaeli, 2006; Antin \& Cheshire, 2010). Three perspectives of lurkers such as free riders (Nonnecke et al., 2004), legitimate peripheral participants (Soroka \& Rafaeli, 2006) and knowledge sharing barriers (Ardichvilli, 2008) such as interpersonal, procedural and technological barriers. Several studies on online communities concentrated on reasons for lurking (Nonnecke \& Preece, 2001; Preece, Nonnecke, \& Andrews, 2004; Lampe, Wash, Velasquez, \& Ozkaya, 2010). The reasons given were reluctance to contribute, privacy, lack of confidence, poor systems, information seeking and peripheral learning (Preece et al., 2004; Preece et al., 2010; Antin \& Cheshire, 2010). Neelen and Fetter (2010) reveal that lurking is a learning strategy for the students. On the other hand, Facebook causes envy that lead to depression (Steers, Wickham, \& Acitelli, 2014; Tandoc, Ferrucci, \& Duffy, 2015). Lurking on Facebook may lead to envy that causes lurkers to feel depress as they compare their lives with their Facebook friends. This finding is consistent with other studies conducted by Smith and Kim (2007) and Salovey and Rodin (1984) which revealed envy and jealousy led to depression.

The popularity of social network sites with the university students and the youths lead lecturers and language teachers to incorporate social network sites in their classrooms despite the scepticism and resistance (Nakatsukasa, 2009; Lockyer \& Patterson 2008). There are many studies conducted using Facebook (Kamaluddeen et al., 2010; Safurah \& Azmi, 2010; Kabilan, Ahmad, \& Zainol, 2010;) as Facebook is the most popular social network site among university students for its application tools (Maslin \& Selisa, 2014). Online discussions using social network sites enable second language learners to learn and acquire the language outside of the traditional classrooms (Perez, 2003; Supyan \& Azhar, 2008). In the context of learning English as a second language, multiple studies indicated the benefits of using online discussions to ESL learners. The benefits of online discussions that L2 learners receive are less threatening sites of study, encourage more participation, improve language outputs, encourage collaborative learning, increase learners' autonomy and promote the zone of ZPD (Chun, 1994; Kern, 1995; Masputeriah, 2006; Supyan, 2008; Warschauer, 1996; Perez, 2003; Amelia, Mohamed, \& Rosseni, 2009; Ranjit \& Mohamed, 2008, Supyan, 2009). Kabilan et al. (2010) reveal that using Facebook assisted L2 learners to enhance their confidence, language skills, motivation and attitude towards learning English language. The students would be able to read the posts as many times as they prefer and to answer the posts any time they like. Thus, online communities are appropriate communities to practise the target language outside of class hours which provides an excellent additional environment for L2 learners.

According to Supyan and Azhar (2008), online communities are alternative language platforms for lecturers and language teachers to continue language practices for their students. Yamada (2009) reveals that text-mediated communication in online group discussions improves learners' confidence in using grammar. Learners improve language proficiency and reading skills (Greenfeld, 2003; Warschauer \& Meskill, 2000; Thang \& Bidmeshkia, 2010). Chuah (2014) indicates that language teachers and lecturers employ comic strips to start a topic, use 
social talks and use the instructions' frequent interventions. The study also indicates the students' sense of belonging influence them to participate not their mastery of the content. Thus, need to improve social elements of the community.

There are not many studies conducted on lurking and lurkers in Malaysia. Regular Facebook activities are listed as posting messages, lurking and posting pictures (Abdullah, Mariah, \& Rahmat, 2014, Pempek and Calvert, 2009 ) to update their information on their friends' activities without contributing to the discussion. Pempek et al. (2009) emphasise that students joined Facebook groups due to demands that did not use the groups to discuss and interact with their groups' members. Similar findings were resonated in a study conducted by Melor and Hadi (2012) as they lament that their participants were distracted by other Facebook applications such as Facebook games and chats. The study focusses on lurking and L2 learners as many studies on L2 learners on Facebook concentrated on writing skills (Ng \& Mahendran, 2015; Azianura \& Khaleel, 2015; Melor \& Hadi, 2012; Melor, Hadi, \& Chen, 2012). Sometimes, students joined Facebook groups to improve their English language proficiency, but did not contribute to the contents of the groups as they wanted access to shared information in the groups, and the groups did not offer their language needs (Kasuma \& Wray, 2015). This study fills the gap by investigating lurking among L2 learners to shed ways to encourage lurkers to produce contents.

\section{The Study}

\subsection{Research Question}

The present study was conducted to examine the behaviours of lurking among L2 learners in a Facebook group. The following research question of the study was mentioned below:

1) Why do L2 learners lurk on a Facebook group?

\subsection{Research Design}

The study employs a qualitative case study. A qualitative case study enables the researchers to gain the in-depth understanding of the participants' experiences to understand the reasons of lurking for three ESL learners.

\subsection{Participants}

The study involved three members of a Facebook group that was called English Language Café (ELC). The current study adopted purposive sampling as it enabled the researchers to select participants based on criterion sampling as the participants fulfilled the criteria of the study: (a) active Facebook users (b) passive participants of the Facebook group discussions. The participants consisted of one male and two female participants aged between 19 to 20 years old. The participants were identified as lurkers and when contacted by the researchers agreed to be involved in the study.

Table 1. Profiles of the participants

\begin{tabular}{llll}
\hline Nickname & Gender & Age & Level \\
\hline Geep & Male & 19 & Intermediate \\
Gomez & Female & 19 & Upper Intermediate \\
Dia & Female & 19 & Upper Intermediate \\
\hline
\end{tabular}

\subsection{Research Context}

The site of the study is a secret Facebook Group as an online learning environment. The group was called as English Language Café (ELC). The site acted as a learning site for ESL students to learn. The participants volunteered to join the group to improve their English. ELC had diploma and degree students as members of the group. The participants were diploma students of a public university in Malaysia. The participants were active Facebook users and were familiar with Facebook groups as they were members of various Facebook groups. Selected participants hold the clues for understanding the phenomena.

\subsection{Data Collection Procedures}

The study involved an online observation of a Facebook group (ELC) and semi-structured interviews with three participants. The participants were participants of a larger research group. Their Facebook accounts and a common Facebook group were observed for 14 weeks, and they were interviewed after the observation. After Week 10, the researchers identified three lurkers based on their non-participation in ELC. Once the participants 
agreed, after the Week 14, they were interviewed. The participants were asked about their experiences of lurking and their reasons for lurking in the Facebook Group.

\subsection{Data Analysis}

Thematic analysis was used to identify repeated patterns of meaning from the experiences of the participants. Data collected from online observation and semi-structured interviewed were analysed and managed using Atlas.ti 7. The participants' semi-structured interviews were audio-taped and transcribed verbatim. Data were analysed and coded using two cycles of coding (Miles, Huberman, \& Saldana, 2014).

\section{Results}

The results of the study are described in term of the reasons given by the lurkers of their lurking preferences based on the research question:

\subsection{Why do L2 Learners Lurk on a Facebook Group?}

The data suggests that there are five significant themes emerged from the participants' interviews and the group discussions.

\subsubsection{Theme 1: Poor Online Communication Skills}

The participants' semi-structured interviews revealed that all three participants had poor online communication skills. In other words, they had poor netiquette. They did not know how to communicate properly in Facebook group discussions. For example, they did not use appropriate language expressions to interrupt, ask, give their opinions, share information with other learners and make sense of the content. In addition, the participants confessed that they lurked as they were afraid that they might insult other group members with their tones, jokes and words. Geep admitted that he did not comment on Facebook groups as he had inadequate online communication skills as he did not know what to contribute:

\section{Extract 1}

It is a closed group. They discuss in English as they are international group. I don't comment because I don't know what to comment ...not because of the language. (Geep)

Geep explained that he lurked in the group not because of his English language proficiency. He was confident in conversing in English, but he did not know how to comment on a Facebook group with international members from different age groups.

In Gomez's case, she disclosed that she refrained herself from commenting in Facebook as she did not want her Facebook friends to misinterpret her words. She explained:

\section{Extract 2}

Gomez in $\mathrm{Fb}$ is not a talkative one. In real life I speak more than I type. Because when we say something with our friends, we don't have the same tone when we send. Some might think differently with what we mean. I find it irritating. (Gomez)

Gomez elaborated that she was more comfortable with face-to-face communication as she was able to explain her intentions more effectively than online communication.

In Dia's case, she specifically mentioned that she only responded to posts that were related to her and when she was compelled to answer. She justified:

\section{Extract 3}

A bit different because in $\mathrm{Fb}$, I am not very talkative. I only comment on posts that are related to me and I think that when I need to comment, I will comment. In real life, I am a talkative person...I will talk...and then because in real life, I am more friendly. (Dia)

Dia realised that she acted differently on Facebook as she was less talkative and friendlier on Facebook. Her responses indicated that she was less skillful in online communication skills.

\subsubsection{Theme 2: Lack of Confidence}

The second emerging theme of the participants' semi-structured interviews indicated that all three participants were not confident of their English language proficiency. The participants acknowledged Facebook as their public places where their Facebook friends from all around the world to be witnesses of their successes and 
failures. It was interesting for the researcher to note that Gomez and Dia talked about how their peers' responses to their replies in English influenced them not to contribute to the discussion. They explained:

\section{Extract 4}

Some of my friends discourage because sometimes when I talk in English they don't want to reply in English. They will reply when I talk in Malay. May be sometimes when we talk in English and the others don't want to talk English. They find it very formal and then it is hard to find the correct vocabulary. Sometimes I just talk in English, they would reply in bahasa. When I continue talking in English, then they wouldn't talk at all. Sometimes yes it hurts you. But that is okay.Then I would talk in Malay.then we continue the conversation. I get the message. (Dia)

\section{$\underline{\text { Extract } 5}$}

Maybe they don't have the confidence to talk in English. Because they not even try to communicate in English. I think they don't have the interest in English. The groups use Malay. For example .school group and batch group. If I write comments in English, some would reply in English. But my schoolmates, they don't reply in English ... some would, the Malays use Malay...When the post in Malay, if we reply in English, others would say...You know...poyo.... a showoff... Of course I don't want to be poyo (Gomez)

In Dia's case, she shared her sorrow when her friends did not want to communicate in English with her. She understood that her friends were not confident with their English language proficiency. Thus, she decided to use Bahasa Melayu to communicate with her Malay Facebook friends. English was reserved for her non-Malay friends. Meanwhile in Gomez's situation, she refused to be labelled as a nerd by her Malay friends. Similar to Dia, Gomez succumbed to her friends' pressure of using Bahasa Melayu in communicating on Facebook.

Geep confessed that he lurked on Facebook groups as he was unable to express himself in English. He stated:

\section{Extract 6}

Because I don't have ideas to talk.most of the ideas are in Malay. When I want to talk English I sometimes little bit slow translating Malay words to English. I lack of vocabulary...They are afraid to use the wrong vocabulary. Some people will laugh and tease them. I don't comment because sometimes I don't know how to comment in English. (Geep)

He further elaborated that he understood the reason people refused to comment in English or simply lurked in the groups due to lack of confidence in communicating in English. Geep stressed that his vocabulary hindered him from contributing to Facebook groups that he joined.

\subsubsection{Theme 3: Learning by Lurking}

The third emerging theme emerged from the interviews revealed that Dia, Gomez and Geep learned many things by lurking. Usually, the Facebook groups the participants joined were communities of interests. Thus, the participants were able to gain knowledge on their interests by reading the updates of the groups. These updates were contributed by active members. The participants learned to construct sentences and increase their vocabulary when they observed comments posted by active participants. They confessed that when they were ready and more confident, they would participate and contribute to the group. Dia confessed she learned recent information and new knowledge from the groups' members. She elaborated:

\section{Extract 7}

Sometimes because I need to know what is happening to the group and I want to get update, information from the group.I read somebody status...Sometimes they write about their own experiences but they use English...That is good and I learn new vocabulary. (Dia)

Apart from information and knowledge about current issues and the groups' interests, she realised she learned to improve her English language proficiency by increasing her vocabulary by reading her Facebook friends' posts and comments.

Gomez explained that the reason they lurked was to learn useful information. She pointed out:

\section{Extract 8}

I do like to observe because they might post something useful. Based on the groups I join, the group that you created. I can improve the language by connect with them by facebook. ..Even though I rarely post. (Gomez)

Gomez realised the importance of collective knowledge contributed, shared and collected by a Facebook group. Gomez lurked to learn useful information relevant to her. She joined Facebook groups to increase her knowledge 
of her interests as she knew the collective knowledge of the members of the groups would enhance her knowledge of that particular area. Lurking was a shortcut to the information she desired.

Similar to Gomez, Geep only read the comments without contributing to the group discussions as he became more informative and knowledgeable about his interest in photography. He illustrated:

\section{Extract 9}

I don't comment but frequently read the comments...I need to learn more. and I just look for the answers. I can see what my friends are doing, what is happening to the world and I like...Photography...Games videos etc. I just read the comments from the professionals. Nowadays I haven't uploaded so much. (Geep)

Geep realised the benefits he reaped when he joined Facebook groups of his interests. For example, when he joined a Facebook group of professional photographers, he learned the tips and techniques to become a better photographer. Thus, he religiously read the posts and comments contributed by the group members.

\subsubsection{Theme 4: Lack of a Sense of Belonging to the Facebook Group}

Lack of a sense of belonging to the Facebook group is a significant theme emerged from the semi-structured interviews. Only Dia and Geep indicated that they lurked in the groups that they did not have any emotional attachment to the groups Dia explained that if a member felt belonged to a Facebook group, he would contribute to the group's discussions. She explained:

\section{Extract 10:}

If the post or comment is related to me. Sometimes if they tag but I don't feel interested, I will not participate/comment ... Not the formal one (post)interested in current issues such as Gaza ... I have one group that has mixed races Malay... Indian and Chinese ... mostly we will communicate in English. In my opinion because they feel more comfortable talking in English.I feel belonging ... Because we feel sisters and brothers and then we can share about our experiences ... Our study ... our going travel anywhere. I am active maybe the confidence level. I contribute because I love the group.because when the program ... When I go to the program ... We feel like we are brothers and sisters ... we can share everything.when some of us go study abroad they share about their experiences and teach us how to apply to go overseas. (Dia)

She elaborated that she was comfortable to contribute in that particular group as they shared many similar interests and experienced. The time spent on the group was continued to offline activities as they had programmes for the members. Dia was active as she joined the offline and online activities of the group. She had vested interest in that Facebook group which was unlike the Facebook group she joined for the research. A similar finding was resonated in Geep's extract. He stated:

\section{Extract 11:}

I do comment in some groups. Photography groups ... I am interested in photography and I want to learn from the experts. They are professional photographers. (Geep)

Geep was not a lurker in Facebook groups that captured his interests such as photography groups. He admitted that he commented on the groups' discussions as he felt his comments were relevant and needed.Furthermore, he wanted to learn from the experts, so he did ask questions to improve his photography skills.

\subsubsection{Theme 5: Lurking is the Norm of Facebook Groups}

Another significant theme emerged from the participants' semi-structured is lurking was regarded as being the norm of Facebook groups by the participants. Dia described her personal experiences as a lurker and how she perceived other lurkers. She explained:

\section{Extract 12}

By communicating with each other in English. Rarely use BM ... can use BM ... everyone knows ... No newcomers ... 120 members ... some of them don't really communicate ... They read...40+ are active. Because when we ask them to meet for reunions, they just like but they don't comment. Sometimes because I need to know what is happening to the group and I want to get update, information from the group (Dia)

Dia reported that many members in one of her Facebook groups lurked and did not participate in the group discussion even when they were asked questions. She claimed that only one-third of the members was active while the rest were lurkers. Furthermore, she admitted that she did lurk when she just wanted to know the recent information about the group and the information from the group. She felt it was normal for the members to be lurkers. 
Gomez confessed that she was a lurker. She explained the main reason she started being a lurker:

\section{Extract 13}

I post rarely, I comment rarely ... I don't reply any message on FB. I think in part 3 ... last year. Because my family is there. My father is a stalker. He likes to comment on my status. Because he likes to comment being sarcastic with me. I don't want my friends to read. (Gomez)

Gomez valued her privacy and friendships with her Facebook friends. She wanted to protect herself from being embarrassed by her family especially her father. In her view, Facebook was a public place that she was scared that her father would embarrass her with his sarcasm in front of her Facebook friends. As lurking was an acceptable practice in Facebook groups, she adopted the practice as she reaped her benefits from the groups that protected her privacy from her family.

Geep justified that he was an observer first. He needed time to be comfortable with the Facebook groups he joined. He described:

\section{Extract 14}

So often (laugh nervously) because I am the type that I like to emmm... I like to observe first. I requested. I mostly I look at the comments. I think the post is not related to me, I will not comment on it A quiet person ... Because I guess I look at the status and sometimes like ... Sometimes not ... Rarely comment (Geep)

Geep explained that his Facebook friends assumed that he was a quiet person as he rarely participated in his Facebook groups' discussions. He confessed that he preferred reading the groups' discussions without participating in the groups' discussions.

\section{Discussions}

The findings indicated that Geep and Dia portrayed that they had five reasons for being lurkers. Meanwhile, Gomez depicted only four reasons for being a lurker.The first reason shared by all the participants was having poor online communication. The researchers noticed that the participants did not collaborate with others, and they did not provide feedback to other participants. As a result, the participants were unable to create a community of learning as they failed to connect socially with other learners by appreciating other learners' efforts and respecting the privacy of others. The findings concur with other studies on the importance of effective online communication skills (Johnson \& Stanne, 2000; Baskin, Barker, \& Woods, 2005; Jahng, Nielsen, \& Chan, 2010). The findings supported the findings of the study carried by Hooper and Kalidas (2012) that indicated that the Netiquette depended on the multiple audiences of the Facebook users. The complexity of the audiences on Facebook requires the participants to possess a wide range of communication skills. The second reason was having a lack of confidence in communicating in English which was faced by Dia, Gomez and Geep. The participants were reluctant to make language errors. Thus, their coping strategy was not to make mistakes at all by not posting or contributing anything to their Facebook groups. The findings supported the study conducted by Preece et al. (2004) that shared the view that the users faced public posting shyness. The findings of the study suggested herding behaviours could explain the behaviours of Dia and Gomez. As mentioned by Hooper and Kalidas (2012), herding behaviour was prominent in the actions of Facebook users to mimic the behaviours of their Facebook friends.

The third reason was lurking enabled learning for Dia, Gomez and Geep. The findings supported Lampe's previous study (2010) that suggested many online group members became lurkers as they were content with gaining the information from the group. However, this study suggested lurkers learned through observation as they were still novices. Novices learnt from the experts mimicking their actions and when they were ready they would be doing the jobs' of the experts. This finding was similar to the study carried out by Antin and Chesire (2010) that propagated that lurkers would become posters once they were familiar and knowledgeable with the group.

The fourth reason was not having a sense of belonging to Facebook groups. The sentiment was shared by Dia and Geep. As pointed out by Farhana, Tan and Abdul Rahim (2015), the members of an online community only participated in online discussions when they felt a sense of belonging. Similarly, the findings of the study indicated that lurking occurred when the members were not committed to the Facebook group. The findings were similar to the findings by Chuah (2014) who advocated that lurkers would participate in topics that they were interested and had a sense of belonging. The final reason was lurking was the norm of Facebook Groups. Dia, Gomez and Geep shared that lurking was an acceptable practice. This finding supported previous studies (Nonnecke \& Preece, 2001; Preece, Nonnecke, \& Andrews, 2004, Antin \& Cheshire, 2010; Benevenuto et al., 2009) that showed lurking was considered as an accepted online activity by the participants. In addition, Kasuma 
and Wray (2015) indicate that the second language learners joined a Facebook group to improve their English language proficiency chose to be lurkers. They did not feel guilty even though they did not participate and contribute to the group discussions. Lurking was an acceptable practice in their Facebook groups.

\section{Conclusions}

The current study investigated the reasons of lurking given by three participants of Facebook groups. It was found that the participants had various reasons for lurking on Facebook groups. The findings suggested that lurkers on Facebook groups often had five reasons: (a) poor online communication skills, (b) lack of confidence, (c) learning from observing, (d) lack of a sense of belonging, and (e) lurking was the norm of Facebook groups.The findings revealed that active participation on Facebook groups would be stimulated if the members were sensitive to the Netiquette so they will adhere to its rules. In addition, lurking emphasized the herding behaviour on the Internet as peer pressure led to conformity that was seen on the way group members determined the choice of the language. Another interesting finding was lurking occurred in groups that the members were not invested in the groups' practices as they had no sense of belonging or emotional attachment to the groups. The last finding reminded the researchers that lurking was an acceptable popular behaviour on the Internet. It is suggested that future studies concentrate on the characteristics of lurkers on Facebook groups and the ways to turn lurkers to contributors.

\section{Acknowledgments}

The researchers thanked Universiti Teknologi MARA Perlis and Universiti Utara Malaysia for their generosity and assistance.

\section{References}

Abdullah, A., Alassiri, M. M., \& Rahmat, G. (2014). Usage of Social Networking Sites and Technological Impact on the Interaction Enabling Features. International Journal of Humanities and Social Science, 4(4), 46-61.

Amelia, A., Mohamed, A. E., \& Rosseni, D. (2009). Development of a collaborative learning community through computer-mediated communication. In M. A. Embi (Ed.), Computer-Mediated Communication: Pedagogical Implications of Malaysian Research Finding (pp. 112-127). Shah Alam: Karisma Publications Sdn. Bhd.

Anderson, C. A., Gentile, D. A., \& Buckley, K. E. (2007). Violent video game effects on children and adolescents: Theory, research and public policy. http://dx.doi.org/10.1093/acprof:oso/9780195309836.001.0001

Antin, J., \& Cheshire, C. (2010). Readers Are Not Free-riders:Reading As a Form of Participation on Wikipedia. Proceedings of the 2010 ACM conference on Computer-supported cooperative work. http://dx.doi.org/10.1145/1718918.1718942

Ardichvilli, A. (2008). Learning and knowledge sharing in virtual communities of practice: Motivators, barriers, and enablers. Advances in Developing Human Resources, 10, 541-554. http://dx.doi.org/10.1177/1523422308319536

Azianura, H. S., \& Khaleel, B. B. (2015). Netspeak and a Breach of Formality: Informalization and Fossilization of Errors in Writing among ESL and EFL Learners. International Journal for Cross-Disciplinary Subjects in Education (IJCDSE), 6(2), 2165-2173.

Baskin, C., Barker, M., \& Woods, P. (2005). When group work leaves the classroom does group skills development also go out the window? British Journal of Educational Technology, 36(1), 19-31. http://dx.doi.org/10.1111/j.1467-8535.2005.00435.x

Benevenuto, F., Rodrigues, T., Cha, M., \& Almeida, V. (2009). Characterizing User Behavior in Online Social Networks. Proceedings of the 9th ACM SIGCOMM conference on Internet measurement conference, 49-62. http://dx.doi.org/10.1145/1644893.1644900

Berhannudin, M. S., \& Wan, F. A. W. M. (2009). Speak it out \& be heard online. In M. A. Embi (Ed.), Computer-Mediated Communication: Pedagogical Implications of Malaysian Research Finding (pp. 112-127). Shah Alam: Karisma Publications Sdn. Bhd.

Bernstein, M. S., Bakshy, E., Burke, M., \& Karrer, B. (2013). Quantifying the Invisible Audience in Social Networks. Proceedings of the SIGCHI Conference on Human Factors in Computing Systems, 21-30. http://dx.doi.org/10.1145/2470654.2470658

Buzzetto-More, N. (2012). Social networking in undergraduate education. Interdisciplinary Journal of Information, Knowledge \& Management, 7, 63-90. 
Chuah, K. M. (2014). Luring the Lurkers: Increasing Participations in the Online Discussions of a Blended Learning Course. International Journal on E-Learning Practices (IJELP), 1(1), 49-58.

Chun, D. M. (1994). Using computer networking to facilitate the acquisition of interactive competence. System, 22(1), 17-31. http://dx.doi.org/10.1016/0346-251X(94)90037-X

Gayo-Avello, D. (2012). I Wanted to Predict Elections with Twitter and all I got was this Lousy Paper-A Balanced Survey on Election Prediction using Twitter Data. arXiv preprint arXiv:1204.6441.

Hooper, V., \& Kalidas, T. (2012). Acceptable and unacceptable behaviour on social networking sites: A study of the behavioural norms of youth on Facebook. Electronic Journal Information Systems Evaluation, 15(3), 259-268.

Farhana, D. D., Rachel, T. H. K., \& Abdul, R. S. (2015). Virtual Communities in an Online English Language Learning Forum. International Education Studies, 8(13), 79-87.

Hannon, J., Bennett, M., \& Smyth, B. (2010). Recommending Twitter Users to Follow Using Content and Collaborative Filtering Approaches. Proceedings of the fourth ACM conference on Recommender systems, 199-206 (RecSys 2010). http://dx.doi.org/10.1145/1864708.1864746

Hew, K. F., \& Cheung, W. S. (2003). An exploratory study on the use of asynchronous online discussion in hypermedia design. Journal of Instructional Science\& Technology, 6(1).

Hiltz, S. R., Turoff, M., \& Harasim, L. (2007). Development and philosophy of the field of asynchronous learning networks. The SAGE Handbook of E-learning Research. London: SAGE Publications.

Jahng, N., Nielsen, W. S., \& Chan, E. K. H. (2010). Collaborative learning in an online course: A comparison of communication patterns in small and whole group activities. Journal of Distance Education (Online), 24(2), $39-58$.

Johnson, D. W., Johnson, R. T., \& Stanne, M. B. (2000). Cooperative learning methods: A metaanalysis. University of Minnesota, Miinneapolis, Minnesota.

Kabilan, M. K., Ahmad, N., \& Zainol Abidin, M. J. (2010). Facebook: An online environment for learning of English in institutions of higher education? Internet and Higher Education, 13(4), 179-187. http://dx.doi.org/10.1016/j.iheduc.2010.07.003

Kamaluddeen, U. D., Jafreezal, J., Rod, A. A. D. L., \& Alan, G. D. (2010). An evaluation of the usage of web 2.0 among tertiary level students in Malaysia. Proceedings of International Symposium on Information Technology 2010 (ITSim 2010). Kuala Lumpur.

Kasuma, S. A. A., \& Wray, D. (2015). An informal facebook group for English language interaction: A study of malaysian university students' perspectives, experiences and behaviours. Paper presented at the 1-10. http://dx.doi.org/10.5176/2251-1814_EeL15.4

Kern, R. (1995). Restructuring classroom interaction with networked computers: Effects on quantity and characteristics of language production. The Modern Language Journal, 79(4), 457-476. http://dx.doi.org/10.1111/j.1540-4781.1995.tb05445.x

Kollock, P., \& Smith, M. (1996). Managing the Virtual Commons: Cooperation and Conflict in Computer Communities. In S. Herring, (Ed.), Computer-mediated communication: Linguistic, social, and cross-cultural perspectives (pp. 109-128). Amsterdam: John Benjamins. http://dx.doi.org/10.1075/pbns.39.10kol

Lampe, C., Wash, R., Velasquez, A., \& Ozkaya, E. (2010). Motivations to Participate in Online Communities. Proceedings of CHI 2010. http://dx.doi.org/10.1145/1753326.1753616

Lockyer, L., \& Patterson, J. (2008). Integrating social networking technologies in education: A case study of a formal learning environment. Proceedings of 8th IEEE International Conference on Advanced Learning Technologies, 529-533. http://dx.doi.org/10.1109/icalt.2008.67

Maslin, M., \& Selisa, U. (2014). Use of Online Social Networking and Academic Performance of Students. Sains Humanika, 2(2), 103-107.

Masputeriah, H. (2006). Use of computer-mediated communication to facilitate second language acquisition. In M. K. Kabilan, N. Razak, \& M. A. Embi (Eds.), Online teaching and Learning in ELT (pp. 159-176). Pulau Pinang: Universiti Sains Malaysia.

Melor, M. Y., \& Hadi, S. (2012). The effectiveness of Facebook groups on Teaching and Improving Writing: 
Students' perceptions. Journal of Education and Information Technologies, 1(6), 87-96.

Melor, M. Y., Hadi, S., \& Chen, C. (2012). Integrating Social Networking Tools into ESL Writing Classroom: Strengths and Weaknesses. English Language Teaching, 5(8), 42-48.

Meyer, K. A. (2004). Evaluating online discussions: four different frames of analysis. Journal of Asynchronous Learning Networks, 8(2), 101-114.

Muller, M., Shami, N. S., Millen, D. R., \& Feinberg, J. (2010). We Are All Lurkers: Consuming Behaviors among Authors and Readers in an Enterprise File-sharing Service. Proceedings of GROUP 2010, ACM Press (2010), 201-210. http://dx.doi.org/10.1145/1880071.1880106

Nakatsukasa, K. (2009). The efficacy and students' perceptions of collaborative blogging in an ESL classroom. In C. A. Chapelle, H. G. Jun, \& I. Katz (Eds.), Developing and evaluating learning materials (pp. 69-84). Ames, IA: Iowa State University.

Neelen, M., \& Fetter, S. (2010). Lurking: A challenge or a fruitful strategy? A comparison between lurkers and active participants in an online corporate community of practice. International Journal of Knowledge and Learning, 6(4), 269- 284. http://dx.doi.org/10.1504/IJKL.2010.038649

Ng, S. P., \& Mahendran, M. (2015). The Effectiveness of Facebook Group Discussions on Writing Performance: A Study in Matriculation College. International Journal of Evaluation and Research in Education (IJERE), 4(1), 30-37.

Nguyen, D., Gravel, R., Trieschnigg, D., \& Meder, T. (2013). How Old Do You Think I Am? A Study of Language and Age in Twitter. Proceedings of ICWSM 2013.

Nonnecke, B. (2000). Lurking in e-mail based discussion lists. London: South Bank University.

Nonnecke, B., \& Preece, J. (2001). Why Lurkers lurk. Proceedings of the Americas Conference on Information Systems.

Nonnecke, B., \& Preece, J. (2000). Lurker Demographics: Counting the Silent. Proceedings of CHI 2000, 73-80. http://dx.doi.org/10.1145/332040.332409

Nonnecke, B., Preece, J., \& Andrews, D. (2004). What Lurkers and Posters think of each other. Proceedings of the 37th Hawaii International conference on System Science.

Nonnecke, B., Preece, J., \& Andrews, D. (2004). What Lurkers and Posters think of each other. Proceedings of the 37th Hawaii International conference on System Science.

Normazidah, C. M., Koo, Y. L., \& Hazita, A. (2012). Exploring English language learning and teaching in Malaysia. GEMA Online Journal of Language Studies, 12(1), 35-51.

Omar, H., Amin, E. M., \& Md. Yunus, M. (2012). ESL learners' Interaction in an online discussion via Facebook. Asian Social Science, 8(11), 67-80. http://dx.doi.org/10.5539/ass.v8n11p67

Pempek, T. A., Yermolayeva, Y. A., \& Calvert, S. L. (2009). College students' social networking experiences on Facebook. Journal of Applied Developmental Psychology, 30(3), 227-238. http://dx.doi.org/10.1016/j.appdev.2008.12.010

Perez, L. C. (2003). Foreign language productivity in synchronous versus asynchronous computer-mediated communication. CALICO Journal, 21(1), 89-104.

Preece, J., Nonnecke, B., \& Andrews, D. (2004). The top 5 reasons for lurking: Improving community experiences for everyone. Computers in Human Behavior, 20(2), 201-223. http://dx.doi.org/10.1016/j.chb.2003.10.015

Ranjit, K., \& Mohamed, A. E. (2008). Async is a synch: What Malaysian adult learners have to say? International Journal of Excellence in e-Learning, 1(2), 1-14.

Ranjit, K., \& Mohamed, A. E. (2010). Learner e-tivities: Exploring Malaysian learners' roles in asynchronous computer-mediated communication. European Journal of Education Studies, 2(2), 157-174.

Ridings, C., Gefen, D., \& Arinze. B. (2006). Psychological barriers: Lurker and Poster motivation and behavior in online communities. Communications of the Association for Information Systems, 18, 329-354.

Romiszowski, A., \& Mason, R. (2004). Computer-mediated communication. In D. H. Jonassen (Ed.), Handbook of research on educational communications and technology (pp. 397-432). Mahwah, New Jersey: Lawrence Erlbaum Inc. 
Safurah, A. J., Khaizuran, A. J., \& Azmi, A. L. (2010). Social Media and our youth today: Exploring the impact of social media on Malaysian youth. Proceedings of International Conference on Communications and Media, Bayview Hotel, Malacca.

Salovey, P., \& Rodin, J. (1984). Some antecedents and consequences of social-comparison jealousy. Journal of Personality and Social Psychology, 47, 780-792. http://dx.doi.org/10.1037/0022-3514.47.4.780

Selwyn, N. (2009). Faceworking: Exploring students' education-related use of Facebook. Learning, Media and Technology, 34(2), 157-174. http://dx.doi.org/10.1080/17439880902923622

Shih, R. C. (2011). Can Web 2.0 technology assist college students in learning English writing? Integrating Facebook and peer assessment with blended learning. Australasian Journal of Educational Technology, 27(Special issue, 5), 829-845.

Smith, R. H., \& Kim, S. H. (2007). Comprehending envy. Psychological Bulletin, 133, 46-64. http://dx.doi.org/10.1037/0033-2909.133.1.46

Soroka, V., \& Rafaeli, S. (2006). Invisible Participants: How Cultural Capital Relates to Lurking Behavior. Proceedings of the 15th international conference on World Wide Web, May 23-26, 2006. http://dx.doi.org/10.1145/1135777.1135806

Steers, M. L. N., Wickham, R. E., \& Acitelli, L .K. (2014). Seeing everyone else's highlight reels: How Facebook usage is linked to depressive symptoms. Journal of Social and Clinical Psychology, 33, 701-731. http://dx.doi.org/10.1521/jscp.2014.33.8.701

Supyan, H., \& Azhar, J. (2008). The prospects of online forum at tertiary level. In A. Ghafur, \& N. A. Razak (Eds.), Policy and implementation of E-learning at institutions of higher learning (pp. 108-122). Bangi: Pusat Pembangunan Akademik UKM.

Supyan, H., \& Azhar, J. (2008). The prospects of online forum at tertiary level. In A. Ghafur, \& N. A. Razak (Eds.), Policy and implementation of E-learning at institutions of higher learning (pp. 108-122). Bangi: Pusat Pembangunan Akademik UKM

Supyan, H. (2008). Creating a bigger Z.P.D. for ESL learners via online forum in Malaysia. College Teaching Methods \& Styles Journal, 4(11), 1-10.

Supyan, H. (2009). Revisiting e-forums in English language teaching \& learning. In M. A. Embi (Ed.), Computer-mediated communication: Pedagogical implications of Malaysian research findings (pp. 90-111). Shah Alam: Karisma Publications Sdn. Bhd.

Swan, K. (2001). Building learning communities in online courses: The importance of interaction. Distance Education, 22(2), 306- 331. http://dx.doi.org/10.1080/0158791010220208

Tandoc, E. C., Ferrucci, P., \& Duffy, M. (2015). Facebook use, envy, and depression among college students: Is facebooking depressing? Computers in Human Behavior, 43, 139-146. http://dx.doi.org/10.1016/j.chb.2014.10.053

Thang, S. W., \& Bidmeshkia, L. (2010). Investigating the perceptions of UKM undergraduates towards an English for science and technology online course. Computer Assisted Language Learning, 23(1), 1-20. http://dx.doi.org/10.1080/09588220903467269

Uysal, I., \& Croft, W. B. (2011). User Oriented Tweet Ranking: A Filtering Approach to Microblogs. Proceedings of the 20th ACM international conference on Information and knowledge management, 2261-2264. http://dx.doi.org/10.1145/2063576.2063941

Warschauer, M. (1996). Comparing face-to-face and electronic discussion in the second language classroom. CALICO Journal, 13(2), 7-26.

Warschauer, M., \& Meskill, C. (2000). Technology and second language learning. In J. Rosenthal (Ed.), Handbook of undergraduate second language education (pp. 303-318). Mahwah, New Jersey: Lawrence Erlbaum.

White, J. (2009). The use of Facebook to improve motivation and academic writing. Proceedings of the Third International Wireless Ready Symposium, 28-32.

Wu, D., \& Hiltz, S. R. (2004). Predicting learning from asynchronous online discussions. Journal of Asynchronous Learning Networks, 8(2), 139-152.

Wu, P., \& Hsu, L. H. (2011). EFL learning on social networking site? An action research on Facebook. Paper 
presented at Teaching \& Learning with Vision Conference, Queensland, Australia.

Yamada, M. (2009). The role of social presence in learner-centered communicative language learning using synchronous computer-mediated communication: Experimental study. Computers \& Education, 52(4), 820-833. http://dx.doi.org/10.1016/j.compedu.2008.12.007

Yunus, M., M., Salehi, H., Huisun, C., \& Yen, J., Y. P. (2012). Using facebook groups in teaching ESL writing. Recent Researches in Chemistry, Biology, Environment and Culture, 75-80.

\section{Copyrights}

Copyright for this article is retained by the author(s), with first publication rights granted to the journal.

This is an open-access article distributed under the terms and conditions of the Creative Commons Attribution license (http://creativecommons.org/licenses/by/3.0/). 